\title{
LEARNING-STYLE BASED ACTIVITIES IN BOOSTING UNDERGRADUATE STUDENTS' TRANSLATION SKILLS: AGRARIAN SPHERE TRANSLATORS' TRAINING
}

\author{
Oleksandr Malykhin, Nataliia Aristova \\ National University of Life and Environmental Sciences of Ukraine, Kyiv, Ukraine \\ E-Mail: malykhinalex1972@gmail.com,n.aristova.na@gmail.com
}

\begin{abstract}
The paper is aimed at presenting theoretical and empirical research on developing learning-style based activities for boosting the translation skills of BA students majoring in English-to-Ukrainian agrarian sphere translation. The participants of the research are $60 \mathrm{BA}$ students taking English-to-Ukrainian agrarian sphere translation at National University of Life and Environmental Sciences of Ukraine. To collect empirical data we used the modality questionnaire developed by O'Brien (1990). The novelty of the study is in combining theoretical and empirical research concerning the learning styles of BA students majoring in English-toUkrainian agrarian sphere translation, developing learning-style based activities aimed at boosting students' translation skills and implementing developed learning-style based activities into the "The Theoretical and Practical Course of English-to-Ukrainian Agrarian Sphere Translation". Learning-style based activities presented in this study might contribute greatly to the development of teaching materials aimed at boosting translation skills of students who major in agrarian sphere translation.
\end{abstract}

Key words: agrarian sphere translators' training, learning styles, learning-style based activities, BA students taking English-to-Ukrainian agrarian sphere translation, higher educational institution

\section{INTRODUCTION}

The increasing digitization of the modern society which deals with all aspects of human activity has already influenced the way people who speak different languages communicate with each other. The appearance of translation apps, their availability and free access to the Internet have changed the people's attitude towards translation profession in general and translators' training in particular. Very often people think that it is enough to speak a foreign language fluently to start translation profession. Moreover, some people even argue that their ability to speak a foreign language fluently and the availability of translation apps can help them get fast translations. But as experience shows fast translations and high-quality ones are completely different things. Despite all technological advances there are many cases where machine translation becomes useless as a translation app cannot convey the actual content of the information that is translated. When translation concerns a specific sphere of human activity it is a degreed translator who knows how to cope with all the difficulties that might arise. But what skills and competences should translators have to be 
considered qualified? What boost translators' skills and what should be taken into consideration in developing training material? To answer these questions we have to understand what translation is. Thus, according to EMT Competence Framework (2017, p. 4) translation is as a multi-faceted profession that covers many areas of competences and skills required to convey the meaning (generally, but not exclusively, in a written medium) from one natural language to another, and the many different tasks performed by those who provide a translation service. It should be noted that during the training competences in such areas as language and culture, translation, technology, personal and interpersonal, service provision have to be developed among students but it is a higher educational institution that specifies the domain-specific types of translation which the students major in. The undertaken theoretical review enables us to state that a single viewpoint on the set of translation skills that have to be developed during the training process is still missing (Coban, 2015; EMT competence framework, 2017; Kamiskienè \& Kavakiauskienė, 2012) and, what is more, training material aimed at boosting translation skills is not generalized. The only thing that educators and researchers agrees on is that any skills can be formed, developed and boosted during the training and understanding the ways in which individual students are trained best can make the training process effective and efficient (Coban, 2015; Kamiskienė \& Kavakiauskienė, 2012; Kolb, 1976, Kolb, 1985; Reid, 1998; Reinert, 1976; Skehan, 1989; Shmeck, 1988).

National University of Life and Environmental Sciences of Ukraine is one of the oldest and the most prestigious higher educational institutions in Ukraine with glorious past and rich in traditions. Close cooperation with world's famous universities provides a rapid reformation of the educational process at National University of Life and Environmental Sciences of Ukraine which contributes to its recognition all over the world. In Ukraine there are many universities which train translators and interpreters but National University of Life and Environmental Sciences of Ukraine is unique as it provides training of BA and MA students majoring in English-to-Ukrainian agrarian translation according to present-day teaching techniques that comply with the world standards. These new standards orient university professors and teachers to search for efficient training techniques and methods which can be made part of the training process aimed at boosting undergraduate translation students' translation skills. Thus, the main aim of the paper is to present theoretical and empirical research concerning the learning styles of BA students majoring in English-to-Ukrainian agrarian sphere translation, to share the experiences of developing learning-style based activities aimed at boosting students' translation skills and their implementing into the "The Theoretical and Practical Course of English-to-Ukrainian Agrarian Sphere Translation”.

\section{The Role Of Learning Styles In Boosting Agrarian Sphere Translators' TRAINING}

Taking into consideration the idea raised by Reinert (1976) that individual learning style is the way in which the person is programmed to learn most effectively, the main objective of the empirical research was to find out the learning styles of undergraduate students majoring in agrarian sphere translation. The results obtained in the empirical research then were used for developing learning-style based activities and their implementing into "The Theoretical and Practical Course of English-to-Ukrainian Agrarian Sphere Translation". The research was carried out among 60 undergraduate translation students at National University of Life and Environmental Sciences of Ukraine in 2017/2018 academic year. 
To determine the learning styles of undergraduate translation students we used the modality questionnaire developed by O'Brein $(1989 ; 1990)$. The questionnaire contained three sections with thirty statements in each section. Students had to indicate how often the statement applied to them, using 3-grade scale: 1 - never applies to me; 2 - sometimes applies to me; 3 - often implies to me. The modality type with the highest score demonstrates student's preferred learning channels. The strongest preference is defined by the highest score. For processing and interpreting the findings of the research we used a descriptive method and methods of mathematical statistics.

The results of the research among BA students taking English-to-Ukrainian agrarian sphere translation are presented in Table 1.

Table 1 Learning styles of BA students taking English-to-Ukrainian agrarian sphere translation

\begin{tabular}{|c|c|c|c|c|c|c|c|c|c|c|c|c|}
\hline \multirow[t]{2}{*}{ Respondents } & \multicolumn{3}{|c|}{ Group 1} & \multicolumn{3}{|c|}{ Group 2} & \multicolumn{3}{|c|}{ Group 3} & \multicolumn{3}{|c|}{ Group 4} \\
\hline & 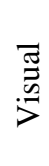 & 苞 & 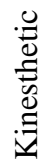 & 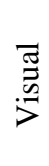 & 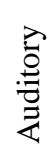 & 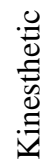 & 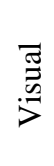 & 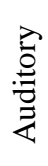 & 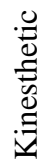 & 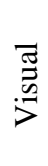 & 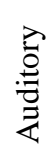 & 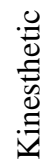 \\
\hline Student 1 & 25 & 20 & 22 & 20 & 18 & 24 & 11 & 25 & 17 & 26 & 19 & 22 \\
\hline Student 2 & 20 & 19 & 22 & 22 & 25 & 12 & 20 & 15 & 12 & 20 & 13 & 19 \\
\hline Student 3 & 23 & 16 & 12 & 21 & 24 & 22 & 23 & 26 & 17 & 19 & 21 & 13 \\
\hline Student 4 & 19 & 22 & 22 & 23 & 17 & 20 & 26 & 19 & 14 & 24 & 18 & 17 \\
\hline Student 5 & 23 & 22 & 23 & 24 & 21 & 16 & 23 & 18 & 11 & 26 & 23 & 17 \\
\hline Student 6 & 13 & 22 & 25 & 23 & 20 & 19 & 21 & 25 & 22 & 19 & 13 & 22 \\
\hline Student 7 & 20 & 14 & 18 & 25 & 19 & 18 & 18 & 21 & 20 & 24 & 22 & 15 \\
\hline Student 8 & 20 & 18 & 22 & 25 & 16 & 21 & 21 & 17 & 20 & 11 & 19 & 15 \\
\hline Student 9 & 23 & 19 & 18 & 22 & 19 & 11 & 26 & 21 & 19 & 21 & 17 & 13 \\
\hline Student 10 & 17 & 16 & 11 & 27 & 22 & 17 & 18 & 13 & 16 & 26 & 20 & 11 \\
\hline Student 11 & 18 & 15 & 16 & 19 & 24 & 10 & 22 & 16 & 13 & 16 & 27 & 19 \\
\hline Student 12 & 20 & 21 & 14 & 23 & 20 & 18 & 24 & 20 & 19 & 18 & 14 & 12 \\
\hline Student 13 & 21 & 17 & 12 & 24 & 19 & 16 & 23 & 21 & 15 & 15 & 19 & 11 \\
\hline Student 14 & 27 & 21 & 15 & 18 & 20 & 23 & 25 & 20 & 22 & 23 & 20 & 17 \\
\hline Student 15 & 22 & 14 & 19 & 21 & 25 & 15 & 22 & 20 & 17 & 25 & 19 & 18 \\
\hline
\end{tabular}

The results presented in Table 1 demonstrate that undergraduate translation students have different learning styles and there is not any well-balanced group. Thus, in group 1 $66.67 \%$ of students have a visual preferred learning channel, $20 \%$ - a kinesthetic preferred learning channel, $6.67 \%$ - an auditory preferred learning channel and $13.33 \%$ of students have more than one strengths. In group $213.33 \%$ of students have a kinesthetic preferred learning channel, $26.67 \%$ - an auditory preferred learning channel, $60.00 \%$ - a visual preferred learning style. In group $326.67 \%$ of students have an auditory preferred learning channel and $73.33 \%$ - a visual preferred learning style. In group $466.67 \%$ of students have a visual preferred learning channel, $26.67 \%$ - an auditory preferred learning channel and $6.66 \%$ - a kinesthetic preferred learning channel. 
The results obtained in the research were used for developing learning-style based activities which were then implemented into "The Theoretical and Practical Course of English-to-Ukrainian Agrarian Sphere Translation". They confirmed the idea that no learning approach is equally effective (Reinert, 1976) for all students who major in translation as visual students usually learn more effectively by seeing or watching demonstrations, auditory students learn better through verbal instructions and kinesthetic students by direct involvement into activities (Reinert, 1976; O'Brein, 1989). The process of improving undergraduate students' translation skills can become more effective if learning-based activities will be used during their training.

\section{IMPLEMENTING OF LEARNING-BASED ACTIVITIES INTO "THE THEORETICAL AND PraCTICAL COURSE OF ENGLISH-TO-UKRAINIAN AGRARIAN SPHERE TRANSLATION”}

\subsection{The description of "The Theoretical and Practical Course of English-to-Ukrainian Agrarian Sphere Translation"}

"The Theoretical and Practical Course of English-to-Ukrainian Agrarian Sphere Translation" is a course for undergraduate translation students who major in English-toUkrainian agrarian sphere translation. The course provides students with theory and practical classes aimed at acquiring necessary skills to translate written texts of different genres of agrarian discourse, to identify any textual difficulties which may arise while translating texts of different genres of agrarian discourse, to analyze and justify the translation solutions, etc. The lectures take 30 hours and practical classes take 60 hours.

Depending on translation students' learning styles we developed activities aimed at teaching students to deverbalize, practice memorization (transformation) and speed translation (Gonzalez Davies, 2004). We used all the learning-style based activities while teaching students the course of "The Theoretical and Practical Course of English-toUkrainian Agrarian Sphere Translation”.

\subsubsection{Activities for deverbalization}

\section{Activity 1: Text referring}

Procedure: Ask students to read a text containing 150-230 words. While reading the text students have to write down up to 10 key words which, in their view, contain the core information. Students are given 3 minutes to read the text and write down the key words. After reading the text and writing down the key words, ask the students to reproduce the information given in the text in writing. The information should be reproduced as close to the text as it is possible. Students are given 5 minutes to complete the task. After checking and correcting the information reproduced by students, ask them to translate the text form English into Ukrainian in writing.

\section{A sample text:}

\section{Oilseed Processing}

Vegetable oil can be extracted from virtually any type of oilseed - soybean, rape seed, cottonseed, etc., - using modern oilseed extraction methods. Two methods are available for extracting the oil - mechanical extraction and solvent extraction.

With mechanical extraction, the seeds are first cleaned, sifted and extraneous portions such as the hulls are removed. The seeds are then crushed and heated, and, subsequently, 
the oil is removed by mechanical means using either a hydraulic pressure or expellers. Pressure is applied to the heated oilseed cake to remove the oil.

Solvent extraction involves immersing the oil seeds in a liquid in which the oil fat dissolves. The solvent is subsequently boiled off and the extracted fat is recovered.

Once the oil is extracted it is often further refined especially if it is to be utilized for human consumption. During the process any remaining sediments are removed from the oil. The oil then is bleached, deodorized and winterized, depending on the seed being processed. Wintering prevents cloudiness in salad oils. Once the oil is refined it is packaged for human consumption or processed further for industrial use - wood oils, lacquers, etc. The high protein cake is normally utilized for animal feed by feed mills or directly by farms with on-the-farm feed mixing.

Variation: A teacher can ask students to listen to the text. While listening to the text students have to write down up to 10 key words which, in their view, contain the core information. The students listen to the text for two times. Then, they are asked to reproduce the information given in the text in the Ukrainian language. They are given up to 5 minutes to complete the task. After checking and correcting the information reproduced by students, they are asked to translate the text form Ukrainian into English in writing.

\section{Activity 2: Text referring}

Preparation: You need as many copies of the text as there are students in the academic group. Each copy should contain different gaps with at least 10 missing words.

Procedure: Ask students to listen to the text containing 150-250 words. While listening to the text, they have to fill in the gaps with the missing words. Tell students they will listen to the text for two times. After listening to the text and checking if they are correct, students are asked to translate the text form English into Ukrainian.

\section{Sample texts: \\ Card 1}

\section{Feed Milling}

When mixing 1) ... two types of mixing systems can be used, namely, batch mixing and continuous mixing. Batch mixing is appropriate for 2) ... feeds of any type - poultry feed, swine feed and cattle feed. With this type of mixing all of the ingredients are first prepared for mixing. It means that after grains and other 3) ... are ground they are placed in the mixers along with a high protein cake and any other supplements required. When the feed is mixed, the batch of feed is then uploaded and transported to storage for loading on trucks or in bags for delivery and use. Batch mixing is normally considered a 4) ... for preparing poultry feed since it allows precise measurement of all ingredients, and poultry feed often requires 5) ... as a medication which require this accuracy of measurement for the sake of safety.

With a continuous mixer, the 6) ... and other ingredients are ground, either separately or together and fed to the mixer continuously. The measurement of ingredients is less precise than with 7) ... mixing because the quantities of ingredients included in the mix are measured by volume rather than by weight. The ingredients are then mixed continuously through the 8 ) ... . Continuous mixing is considered adequate for preparing dairy feed concentrates since this type of feed is normally used to supplement the other feeds 9) ... by the animals. Thus, less precise 10) ... are required when producing this type of feed.

(Missing words: 1) feed; 2) manufacturing; 3) ingredients; 4) requirement; 5) supplement; 6) grain; 7) batch; 8) mixer; 9) consumed; 10) measurements). 
Card 2

\section{Feed Milling}

When mixing feed two types of mixing 1) ... can be used, namely, batch mixing and continuous mixing. Batch mixing is appropriate for manufacturing feeds of any type - poultry feed, 2) ... feed and cattle feed. With this type of mixing all of the ingredients are first prepared for 3) ... . It means that after grains and other ingredients are ground they are placed in the mixers along with a high 4) ... cake and any other supplements required. When the feed is mixed, the batch of feed is then uploaded and transported to storage for loading on trucks or in bags for 5) ... and use. Batch mixing is normally considered a requirement for preparing 6) ... feed since it allows precise measurement of all 7) ..., and poultry feed often requires supplement as a medication which require this accuracy of measurement for the sake of safety.

With a continuous mixer, the grain and other ingredients are ground, either separately or together and fed to the mixer continuously. The measurement of ingredients is less precise than with batch mixing because the quantities of ingredients included in the mix are measured by volume rather than by 8 ) ... . The ingredients are then mixed continuously through the mixer. Continuous mixing is considered adequate for preparing dairy feed concentrates since this type of 9) ... is normally used to supplement the other feeds 10) ... by the animals. Thus, less precise measurements are required when producing this type of feed.

(Missing words: 1) systems; 2) swine; 3) mixing; 4) protein; 5) delivery; 6) poultry; 7) ingredients; 8) weight; 9) feed; 10) consumed).

\section{Activity 3: Text referring}

Preparation: Prepare the cards with words or numbers from the text.

Procedure: A teacher hands out the cards with words or numbers from the text to the students. Then, the students are asked to cross out the words in the cards while listening to the text. A student who is the first one to cross out all the words in his/her card is considered to be a winner.

After listening to the text in the English language, students are given 5 minutes to reproduce the information in written form in the Ukrainian language using the words in their cards. The information should be reproduced as close to the text as it is possible. Then, checking and correcting the information reproduced by students, they are offered to translate the text form Ukrainian into English. Finally, after translating the text from Ukrainian into English students are given the original text for the comparative analysis.

\section{Samples of cards for students:}

Card 1

\begin{tabular}{|c|c|c|c|}
\hline equipment & shifts & work & foreign \\
\hline $10.5 \%$ & period & Ukraine & day \\
\hline
\end{tabular}

\section{Card 2}

\begin{tabular}{|c|c|c|c|}
\hline profit & company & partners & legal \\
\hline facility & 284 & farm & approximately \\
\hline
\end{tabular}

Card 3

\begin{tabular}{|c|c|c|c|}
\hline shifts & profit & Equipment & facility \\
\hline work & 284 & Ukraine & legal \\
\hline
\end{tabular}




\section{A sample text:}

\section{Dutch-style cheese production in Ukraine}

A farm in Ukraine sought and entered into a joint venture with a foreign company to produce on the farm a specific "Dutch-style cheese". The joint venture began in 1993. The cheese processing operation was a private, legal entity. Equipment and training were arranged between the joint venture partners. Other contractual arrangements included profit sharing and responsibilities of parties.

The cheese processing facility made cheese in a 900-liter cheese vat. Depending on the season, up to three shifts could work in the cheese facility. During peak milk production periods, three shifts operate in the cheese facility, manufacturing cheese from 2700 litres of milk per day.

Cheese yield was approximately 10.5\%. 284 kilograms of cheese was produced per 24-hour period from the 2700 liters of milk per day.

Variation: After listening to the text in the English language, students are given 5 minutes to reproduce the information in the English language using the words in their cards in writing. The information should be reproduced as close to the text as it is possible. After checking and correcting the information reproduced by students, students are asked to translate the text form English into Ukrainian.

\section{Activity 4: NO WORDS}

(Recording of information using the language of symbols, sketches or signs).

Procedure: Before doing this activity students are given some examples of substituting words with symbols, signs or sketches:

$\begin{array}{ll}? & \text { a question } \\ ? ? ? & \text { a problem } \\ * * & \text { the weather } \\ *:- & \text { the sun } \\ \delta / \delta & \text { music / a song/ a concert } \\ \$ & \text { money / investment }\end{array}$

Then, tell students that they will listen to the text. While listening to the text students have to record information using symbols, sketches or signs. (Students listen to the text for two times). After listening to the text students have to reproduce it using prompts in the forms of symbols, sketches or signs. Students are given 5 minutes to complete the task. After checking and correcting the information reproduced by students, they are asked to translate the text form English into Ukrainian.

\section{A sample text}

Small investments in semi-hard or hard-cheese production

Some dairy products can be manufactured on the farm with small investments in equipment and training. Examples of product are semi-hard or hard-cheese varieties such as "Dutch-style cheese", "American-style cheese" or some varieties of "Swiss-style cheese". Although it may be thought that a large investment in equipment and training is necessary, minimal equipment can be efficiently used to manufacture high-quality and consistently acceptable cheese varieties.

Cheese vats of small to medium capacities (250 liters to 2000 liters) can be purchased in many parts of the world as "used equipment". The prices for this used equipment are 
lower that the price of the new equipment. Many outlets in Western Europe and in the United States sell used and reconditioned dairy equipment at large savings to the prospective purchasers.

Variation: Ask students to read a text. While reading it students have to record information mentioned in the text using symbols, sketches or signs. No single word should be used to reproduce the information given in the text. Give students 3 minutes to complete the task.

After completing the task, ask students to hand in the cards with the text. Then, ask students to reproduce the text using prompts in the forms of symbols, sketches or signs in writing. Give students 3 minutes to complete the task. After checking and correcting the information reproduced by students, ask students to translate the text form English into Ukrainian.

\subsubsection{Activities for transformation}

The following activities are developed for improving undergraduate translation students' transformation skills.

Activity 1: Transformation of lexical units

Preparation: Prepare a set of cards with words and word-combinations.

Procedure: Ask students to find synonyms to words and word-combinations given to them.

\section{Sample cards}

Card 1

\begin{tabular}{|c|c|c|c|c|}
\hline a production & an investment & dairy products & $\begin{array}{c}\text { minimal } \\
\text { equipment }\end{array}$ & large savings \\
\hline outlets & cheese facility & cheese vats & batch mixing & animal feed \\
\hline $\begin{array}{c}\text { human } \\
\text { consumption }\end{array}$ & industrial use & joint venture & poultry feed & $\begin{array}{c}\text { mechanical } \\
\text { extraction }\end{array}$ \\
\hline
\end{tabular}

Card 2

\begin{tabular}{|c|c|c|c|c|}
\hline a method & mechanical & a plant & a type & vegetables \\
\hline involve & dairy farm & yield & a vat & cattle feed \\
\hline hydraulic & a mixer & extraction & medication & dairy equipment \\
\hline
\end{tabular}

Activity 2: Speech transformation

Procedure: Ask students to listen to a short newspaper article containing up to 500 signs. Students listen to the text for two times. Then, they are given 3 minutes to reproduce the information given in the text in the same language but using different words in writing.

\section{A sample text}

Using modern oilseed extraction methods vegetable oil can be extracted from any type of oilseed. These methods include either mechanical or solvent extraction. Mechanical extraction involves production of oil using such mechanical means as a hydraulic pressure or expellers. To remove the oil a hydraulic pressure is applied to the heated oilseed cake. Unlike the mechanical extraction, solvent extraction involves immersing the oil seeds in a liquid in which 
the oil fat dissolves. Once the oil is extracted it is often further refined especially if it is to be utilized for human consumption.

\subsubsection{Activities for speed translation}

The following activities are developed for improving students' skills in speed translation.

Activity 1: Dictation-translation

Preparation: Prepare a list of words and word-combinations on the topic.

\section{A sample list of words and word-combinations}

animal feed, human consumption, an industrial use, a solvent extraction, the remove the oil, bleached oil, crushed and heated seeds, extraneous portions, soybean, rape seed, rape seed oil, salad oils, cloudiness, hydraulic pressure, oilseed cake, vegetable oil, an oilseed extraction method; feed mills, poultry feed, the accuracy of measurement, deodorized oil, oil wintering

Procedure: Ask students to translate the words and word-combination you dictate from English into Ukrainian. Then, ask the students to do the back-translation from Ukrainian into English.

Variation: Ask students to write down the words and word-combination you dictate in their copy-books. Then, ask the students to translate the written words and wordcombinations from English into Ukrainian.

\section{CONCLUSION}

The main aim of the paper was to present theoretical and empirical research on developing learning-style based activities for boosting the translation skills of BA students majoring in English-to-Ukrainian agrarian sphere translation. The conducted research led to the following conclusions: learning-style based activities implemented into "The Theoretical and Practical Course of English-to-Ukrainian Agrarian Sphere translation" enabled to achieve better results in boosting undergraduate students' translation skills. Although learning-style based activities presented in this study might contribute greatly to the development of teaching materials aimed at boosting translation skills, more research should be carried out to investigate the influence of preferred learning channel on translators' academic performance.

\section{REFERENCES}

Coban, F. (2015). "Analysis and training of required abilities and skills in translation in the light of translation models and general theories of translation studies", Procedia Social and Behavioral Sciences 197:707-714, DOI: 10.1016/j.sbspro.2015.07.074

EMT Competence Framework, (2017). Retrieved December 10th, 2018, from https://ec.europa.eu/info/sites/info/files/emt_competence_fwk_2017_en_web.pdf Gonzalez Davies, M. (2004). Multiple Voices in the Translation Classroom: Activities, tasks and projects, Benjamins Translation Library, $259 \mathrm{p}$. 
Kamiskienè, L., Kavakiauskienè, G. (2012). "Competences in Translation and Interpreting”, Studies About Languages, 20: 138-145, http://dx.doi.org/10.5755/j01.sal.0.20.1772

Kolb, D. (1976). The learning style inventory: Self-scoring test and interpretation. Boston, MA: McBer.

Kolb, D. (1985). Learning style inventory (rev. ed.). Boston, MA: McBer.

O’Brien, L. (1990). Learning channel preference checklist. Rockville, MD: Specific Diagnostic Services.

O’Brien, L. (1989). Learning Styles: Make the Student Aware”, National Association of Secondary School Principals Bulletin, 73: 85-89.

Reid, J. (1998). Understanding learning styles in the second language classroom. UpperSaddle River, NJ: Prentice-Hall Regents.

Reinert, H. (1976). "One picture is worth a thousand words? Not necessarily!", The Modern Language Journal, LX (4):160-168.

Reinert, H. (1971). "Practical Guide to Individualization", The Modern Language Journal, 55 (3): 156-163.

Skehan, P. (1989). Individual differences in second-language learning. London: Edward Arnold.

Schmeck, R. (1988). Learning strategies and learning styles. New York: Plenum. 